\title{
U Karaimów w Haliczu 1
}

\section{GRZEGORZ SMÓLSKI}

W czasie świąt wielkanocnych bieżącego roku przedsięwziąłem wycieczkę do Halicza, starego grodu kniaziów Halickich, który dał nazwę dzisiejszemu królestwu Galicji. Halicz nęcił mnie oddawna swojemi osobliwościami. Dzisiejsze miasteczko z niespełna 5000 ludności, leżące na prawym brzegu Dniestru, w stosunkowo wązkiej dolinie, między rzeką Łukwią, wpadającą tu do Dniestru, a stromą ścianą grzbietu płaskowzgórza, wybiegającego od Karpat - osłania mgła wielkiej przeszłej sławy dziejowej. Mówię mgła, gdyż lubo dziejowa świetność i znaczenie kniaziego prastarego grodu uwiecznione są w kronikach ruskich, polskich i węgierskich, dziejopisowie i starożytnicy wiodą do dziś dnia spór pomiędzy sobą o to, gdzie właściwie leżał stary Halicz. (...) ${ }^{2}$ W szczegóły sporu niepodobna jest wnikać, gdyż to przekraczałoby ramy rzeczy niniejszej. Stwierdzam tylko, że dzisiejszy Halicz osłania mgła dziejowa, przynajmniej pod względem topograficznym i że ze względu na nierozstrzygnięty spór pomiędzy uczonymi nastręcza jeszcze bardzo dużo pola do nowych badań. Faktem jest że, zwiedzając teraźniejszą miejscowość, zawołać można: hec locus ubi fuit Troja ${ }^{3}$. Ślady dawnej świetności stołecznego grodu potężnych kniaziów zupełnie zatarte, a to, co jest, przedstawia się jako licha mieścina, przeważnie przez Żydów zamieszkana, w której jednopiętrowe kamienice dadzą się łatwo policzyć na palcach jednej ręki. Z soboru, monasterów, cerkwi i zamku książęcego, dworców butnych bojarów nie pozostały nawet gruzy, gdyż wszystko, co dzisiejszy Halicz posiada starożytnego, pochodzi z znacznie późniejszych, podziejowych, że się tak wyrażę, czasów. Ruiny zamku na wzgórzu przy miasteczku pochodzą już z „polskich czasów”. Są to szczątki zamku, przebudowanego przez Andrzeja Potockiego w połowie wieku XVII, a pierwotnie wzniesionego przez króla Kazimierza Wielkiego. Obwarowania góry, pierwotne, mogą sięgać swym początkiem jeszcze prastarych ruskich czasów. Ruska cerkiew i kościół katolicki posiadają stary wygląd. Facjata kościoła okazała i piękne ozdoby architektoniczne, jednak zarówno cerkiew jak i kościół są znacznie późniejszej budowy, nie star-

\footnotetext{
1,Naokoło Świata”, 1903 r. (zachowano pisownię oryginału).

2Skróty w tekście pochodzą od redakcji.

${ }^{3}$ Oto miejsce, gdzie stała Troja.
} 
szej z pewnością jak zamek, rozpadły w gruzy. Prócz tych trzech zabytków przeszłości nie widać w miasteczku zgoła niczego, co by prastarą jego przeszłość i świetność mogło choćby w czemkolwiek przypominać. Stary gród Halicz - to, czego ręka dziczy tatarskiej i okropieństwa wojen nie zniszczyły, pogrzebany jest głęboko w ziemi i wykopaliska jedynie składają świadectwo o jego przeszłości i sławie. (...)

Prócz aureoli dziejowej, gubiącej się w mgle stuleci, posiada Halicz dzisiejszy osobliwość etnograficzną nie lada. Jest w nim bowiem jedyna nietylko w Galicji, lecz także w całej środkowej i zachodniej Europie osada karaimów lub karaitów. (...) Jest to w pełnem słowa tego znaczeniu minjaturowy ludek, którego liczba w samym Haliczu i sąsiedniej wsi Załukwi wynosi podług spisu ludności z zeszłego roku 181 osób, do czego można doliczyć jeszcze kilkanaście osobników karaimskich, bawiących za obrębem rodzinnej swej miejscowości dla egzystencji lub polepszenia doli, tak, że liczba galicyjskich karaimów mało co dwie setki przekracza. Dawniej były w Galicji albo raczej na Czerwonej Rusi jeszcze dwie ich osady: jedna we Lwowie, druga w miasteczku Kukizowie. niedaleko Lwowa. Pierwsza osada wymarła zupełnie i już oddawna nie ma karaitów we Lwowie. Kukizowscy osadnicy w większej części także wymarli, w małej zaś przesiedlili się do Halicza. Na Litwie są osady karaimskie w Poniewieżu, Wilnie i Trokach, zaś na Wołyniu w Łucku.

Tadeusz Czacki w przypisku do dzieła „O litewskich i polskich prawach” przytacza, że „w czasie rewizji głów żydowskich w r. 1790 w Litwie i Polsce było karaimów 2,184; dołączając do tego taką liczbę kobiet, wypada liczba wszystkich karaimów (całej ludności karaimskiej) 4,368." Do Polski przybyli oni prawdopodobnie z Krymu, gdzie główne znajdują się po dziś dzień ich siedliska: świadczy o term ich narzecze tatarskie, używane w Haliczu, w którem znajduje się dużo naleciałości polskich, ruskich i hebrajskich. Dwie pierwsze kategorje naleciałości obcych tłómaczy się ich życiem od wieków wśród polskiej i ruskiej narodowości. Wszak tworzą oni od wielu wieków małe wysepki w morzu tej ludności. Hebrajskie naleciałości wyjaśnia, (...) okoliczność, że ich językiem religijnym i liturgicznym, a więc niejako i piśmiennym w ściślejszem słowa znaczeniu (...) jest hebrajski.

Dr. Radłow, który studjował narzecza krymskich, litewskich i wołyńskich karaimów i wydał duży słownik tych narzeczy, dowiódł, że litewscy i wołyńscy karaimi używają narzeczy, pokrewnych mowie krymskich karaimów, która jest tatarską. Są one leksykalnie, fonetycznie i morfologicznie bardzo zbliżone do ostatniej. Galicyjskie narzecze karaimskie pominął dr. Radłow. Lukę tę wypełnił polski uczony Jan Grzegorzewski, studjując je na miejscu w Haliczu, czego owocem jest naukowa rozprawa, napisana po niemiecku p.t. Ein türktatarischer Dialekt in Galizien, ogłoszona w tegorocznych sprawozdaniach z posiedzeń Cesarskiej Akademji Umiejętności w Wiedniu.

T. Czacki i profesor Szarłowski stwierdzają wprawdzie, że karaimi zarówno na Litwie jak i na Rusi używają, jako swojego języka, mowy tatarskiej. Z polskich pisarzów jednak, o ile mi wiadomo, nikt narzecza karaimskiego bliżej nie roz- 
trząsał i nie badał. Były nawet wątpliwości pod tym względem. Niektórzy bowiem sądzili, że to narzecze jest zlewkiem kilku języków wschodnich. Dopiero J. Grzegorzewski rozproszył wszelkie wątpliwości pod tym względem, uzasadniając, że mowa halickich i łuckich karaimów tworzy dwa podrzecza turkotatarskiego wspólnego narzecza wobec innych narzeczy polsko-litewskich karaimów (trockich i poniewieskich). Autor oznajmia w swojej powyżej wspomnianej rozprawie naukowej, że pracuje nad obszernem dziełem o karaimach z tekstami i słownikiem. U nas, prócz Czackiego, prawie nikt nie zajmował się bliżej karaitami w piśmiennictwie, nie mówiąc już o naukowem wyczerpaniu przedmiotu. Dlatego żałować należy, że polski uczony studjum swe naukowe o narzeczu karaimów w Galicji, które byłoby pierwszą ściśle naukową pracą na tem polu w naszem piśmiennictwie, ogłasza w obcym języku4 ${ }^{4}$. Nie można sobie zjawiska tego inaczej wytłumaczyć jak term, że... nemo propheta in patria ${ }^{5}$, zwłaszcza u nas. Nie wiem, lecz przypuszczam, że autor kołatał prawdopodobnie na próżno do bram ojczystych, a nie znalazłszy nakładcy dla swej pracy ściśle naukowej, zniewolony był szukać przytułku u obcych. Niestety, u nas tylko powieści są rozchwytywane przez nakładców.

Karaimi przyszli do Polski w pierwszej połowie XIV wieku. W Haliczu, Lwowie i Kukizowie osiedlili się w r. 1315. Tak jest zapisane w ich historycznym kalendarzu, pisanym tradycyjnie z roku na rok od niepamiętnych czasów przez rabinów hebrajskiem pismem na ozdobnej grubej karcie papieru, oprawionego w złocone ramy i pod szkłem znajdującego się w ich świątyni halickiej. Kalendarz zawiera całą ich historyczno-religijną chronologię: od stworzenia świata, od Mojżesza, od religijnego rozłączenia się karaimów od żydów, od osiedlenia się w rozmaitych miejscowościach na obczyźnie, w szczególności w Galicji i t.p.

W kalendarzu tegorocznym zapisano, jak mi czytał z niego Samuel Mordkowicz, dzierżący klucze od świątyni, że od czasu przybycia Karaimów do Halicza jest 658 lat, zatem, że przybyli oni w r. 1345, po podbiciu Rusi Czerwonej (1340) przez Kazimierza Wielkiego, zapewne przez niego osiedleni i obdarowani rozmaitemi swobodami. Halicz miał od tego króla polskiego prawo magdeburskie. Lustracja miasta Halicza, przedsięwzięta około r. 1580, podaje pierwszą wiadomość o osiedleniu Karaimów w Haliczu. Z tego przyjęto mylną datę ich przybycia na Ruś Czerwoną, oznaczając czas ich osiedlenia się w tym kraju około r. 1580 za panowania Stefana Batorego, co jest mylne, gdyż niema najmniejszego powodu do przypuszczania, żeby data ich przybycia do Halicza, umieszczona na kalendarzu, wiszącym w tamtejszej świątyni, miała być nieprawdziwą. (...)

Nazwa karaimów pochodzi, podług T. Czackiego i innych uczonych badaczów, od wyrazu kara, znaczącego w babilońskim, chaldejskim i hebrajskim języku: pismo, co w zastosowaniu do tej sekty oznacza, wyznawców pisma, badaczów pisanego słowa. Karaim jest hebrajską liczbą mnogą, zatem karaimi lub karaimowie zawiera w sobie podwojoną liczbę mnogą. Niemieccy uczeni obli-

4W jęz. polskim praca ta ukazała się w Roczniku Orientalistycznym, Kraków 1917 r. (red.).

${ }^{5}$ Nikt nie jest prorokiem we własnym kraju. 
czają ogólną liczbę karaimów na świecie na $12.000^{6}$ głów z czego na Krym przypada około 4000 dusz. Prócz Litwy, Wołynia, Galicji, Krymu i Odesy mają oni liczną gminę w Konstantynopolu, gminę w Jerozolimie, Aleksandrji i kilka gmin w Persji. Czacki podaje stanowczo za nizką ich liczbę, przytaczając podług Don Calmeta: „Dictionaire de la Bible” ogólną liczbę ich ludności na niespełna 5000, z czego na Polskę przypada 2000, a więc przeszło o połowę mniej, aniżeli z ilustracji z r. 1700 wynika. Prócz powyżej przytoczonych miejscowości liczy Don Calmet karaimów 300 w Kairze, 200 w Damaszku, w Babilonie 100, a w Persji 600. Dokładnego obliczenia ludności karaimskiej, jak z sprzecznych podań wynika, nie ma nigdzie, tak że tylko w przybliżeniu da się owa liczba ich ludności oznaczyć. (...)

T. Czacki pisze o Karaimach: „Nie szukajmy u nich nauk, ale szanujmy tych prostaków cnotę. Akta świadczą, że karaita o zbrodnię przez cztery wieki nie był w kraju naszym przekonanym. Największe nagrody i postrachy nie wymogły na którymkolwiek z nich, aby był szpiegiem. Furmanka, mały handel, jest źródłem ich zysków. Ubodzy, ale pracowici, w pracy rąk szukają funduszu do życia”. Dawne prawa polskie i litewskie nie czyniły różnicy pomiędzy żydami a karaimami. T. Czacki, wyznaczony w r. 1787 przez komisję skarbową do objazdu województw południowych, poznawszy bliżej karaimów, uczynił wniosek, żeby ich uwolniono od pogłównego, jakie żydzi płacili. Po objęciu Galicji przez Austrję zrównano karaimów pod względem praw z chrześcijanami, a ograniczenia prawne, stosowane do Żydów przed ich równouprawnieniem w Austrji, nie odnosiły się do karaimów. Miasto Kale w Krymie (...) jest duchowno-religijną stolicą karaimów, gdzie przebywa zwierzchni ich rabin, głowa sekty. On rozstrzyga wszystkie ważniejsze sprawy nietylko krymskich, lecz także wołyńskich, litewskich a nawet halickich karaimów. Różnicę celniejszą pomiędzy karaimami a żydami określa T. Czacki w następujący sposób: „Lubo przestrzegają ściśle tylko słowa pism Mojżesza, a talmud zupełnie odrzucają, nie gardzą - jak mówią, dziedzicznem podaniem. U karaimów jeden tylko Elias Ben Moses jest uważany, którego dzieło szanują jako prawo. W talmudzie zachodzą dysputy różnie mniemających, w Oddereth, księdze karaimów, są tylko proste przepisy. Od Żydów różnią się: w obrządkach religijnych, w większej ścisłości małżeństwa, trudności rozwodów, innym sposobem obrzezania, innym zachowywaniem świąt, innemi przepisami w jadle, innem rachowaniem początku miesiąca i t.p. Równie prawa ich cywilne różnią się od praw Żydów rabinistycznych. Jest u nich, jak już powyżej wspominałem, dozwolone wielożeństwo, podczas, gdy u Żydów talmudystów jest to pod klątwą zakazane. Karaimowi wolno mieć więcej żon, lecz najwięcej cztery, jeśli ma je czem wyżywić i powinność małżeńską dla wszystkich żon odbywa.

Na Litwie, Wołyniu i w Galicji karaimi mają zwyczajowo po jednej tylko żonie. Przy zawieraniu małżeństwa nie patrzą na lata, ale na znaki dojrzałości obojej płci. Wdowy i rozwódki, swoją wolą wybierają mężów. Małoletnie dziewczyny

${ }^{6}$ Autorowi chodzi oczywiście o wyznawców religii, a nie przedstawicieli grupy etnicznej (red.). 
tylko zaręczać może ojciec. Rozwody są znacznie trudniejsze, aniżeli u żydów. Mąż nie dziedziczy nigdy po żonie. Wiano pozostaje jej i rodziny zupełną własnością. Przyczyny do rozwodu są: bezdzietność przez lat dziesięć; jeżeli by żona była głucha, ślepa, ust śmierdzących lub zupełnie głupia; jeśli jedno z małżonków nie zachowuje świąt i jada rzeczy zakazane; gdyby małżonek obcował z innemi kobietami; gdyby powinności małżeńskiej z uporu odmawiano. Dla żony są powody do rozwodu: jeśliby mąż odjechał i z inną się ożenił, gdyby żony żywić i odziewać nie chciał. Karaimi kończą spory sądowe pomiędzy sobą prędko. Rabini i starsi są więcej pośrednikami niż sędziami, którzy skłaniają strony opierające do zgody, a tylko w nadzwyczaj rzadkich wypadkach wydają wyroki".

Wszystko, o czem mowa, utrzymało się prawie nieskazitelnie u Karaimów halickich, jak o tem miałem sposobność przekonać się na miejscu.

Miasto Halicz oddalone jest od dworca kolejowego, mniej więcej o półtorej wiorsty. Z dworca dobrze utrzymana droga i wyborne chodniki, jakie gdzie indziej w Galicji Wschodniej bardzo rzadko się spotyka, wiodą do mostu na Dniestrze, po którego przebyciu, staje się zaraz w mieście, na głównej ulicy, tuż przy rynku. Drogi i chodniki z dworca do miasta, starannie utrzymane, wysadzone drzewami, z pięknemi murowanemi domami w ogrodach, rozsianemi dość licznie na przestrzeni między dworcem kolejowym a Dniestrem, sprawiają na podróżniku bardzo dobre wrażenie. Znać w tem przebłyski kultury i cywilizacji, z czego widać, iż zarząd miasta znajduje się w ręku męża porządku i postępu. Jakoż i w całem mieście, a właściwie w mieścinie, widać to samo. Wszędzie porządek, czystość, drogi dobrze utrzymane, a po obydwu ich stronach porządne chodniki. Miasteczka takie, jak Halicz, a nawet i większe, bywają w Galicji Wschodniej istnemi śmietnikami, pełne brudu, kału i cuchnącej woni. Z Halicza można wziąć przykład, że jeżeliby burmistrze tych miasteczek - śmietników, spełniali tak sumiennie i ściśle obowiązki swoje, jak burmistrz Halicza, zmieniłyby się w najkrótszym czasie do niepoznania i przestałyby stanowić istną sromotę dla kraju. (...).

Wzorowy burmistrz Halicza, p. Michał Sawicki, przynosi w szczególności polskim dziennikarzom zaszczyt. Wyszedł on z ich grona. Przed mniej więcej szesnastu laty był redaktorem i wydawcą „Dziennika Polskiego" we Lwowie, następnie, opuściwszy dziennikarstwo, zwrócił się do notarjatu, a zostawszy notarjuszem w Haliczu, został niedługo potem głową miasta. Zaopatrzony jego poleceniem, udałem się do dzielnicy karaimskiej ${ }^{7}$, znajdującej się w pobliżu rynku. Jest to właściwie tylko jedna długa ulica Karaimska, dawniej wyłącznie przez karaimów zamieszkana. Dziś (...) jest przy niej kilka domów żydowskich i w domach karaimskich jest kilku lokatorów żydowskich, co wobec notorycznie wrogich stosunków, panujących pomiędzy karaimami a żydami, dziwne nieco sprawia wrażenie. Poruszyłem to w rozmowie z Samuelem Mordkowiczem, do którego,

7Większość domów znajdujących się przy ulicy Karaimskiej spłonęła w pożarze w 1913 r. Po tym nieszczęściu spora część Karaimów przeprowadziła się w inne rejony miasta oraz do wsi Załukiew i ludność karaimska przestała dominować wśród mieszkańców tej ulicy (red.). 
jako dzierżącego klucze od świątyni karaimskiej, zwróciłem się najpierw z polecającym biletem burmistrza Sawickiego.

- My jesteśmy, mówił, zeznania (wyznania) Mojżeszowego, Talmudu nie znamy, lecz Boże przykazania wykonywujemy ściśle. U nas znaczy: Kochaj bliźniego jak siebie samego, dlatego my, widząc w każdym, nawet w naszym wrogu bliźniego, nikogo nie nienawidzimy, a więc i Żydów. Jeżeli Żydzi nas nie lubią, to ich, nie nasza rzecz.

- Dla czego Żydzi nienawidzą karaimów? - zapytałem.

- Głównie dla tego, że oni twierdzą, jakoby nasze zeznanie (wyznanie) wywołało Chrystusa. Mówią oni, że chrześcijanie powstali z karaimów. Potem, nie lubią nas dlatego, że u nas talmud nic...

Ulica karaimska ma prawie znamię wiejskie. Znajduje się w stanie pierwotności sielankowej. 0 bruku, chodnikach ani mowy. Zwyczajna droga, przy której w pewnych oddaleniach stoją przyziemne domy, w części drewniane, w bardzo małej części murowane, bocznym frontem ku niej zwrócone, domy podługowate z zabudowaniami i ogrodami. Zewnętrzny już wygląd domów okazuje, że ich mieszkańcy zajmują się przeważnie rolnictwem, a także rękodzielnictwem i drobnem kupiectwem. Pomiędzy rękodzielnikami najwięcej jest cieślów. Domy stanowią rodzaj odrębnego typu. Przez dużą wjazdową bramę wchodzi się do szerokiego, dłuższego przedsionku, ciągnącego się przez całą długość domu, bocznym frontem do ulicy przytykającego. Brama i przedsionek znajdują się na lewym skraju domu, przy wejściu do niego. Po prawej ręce przedsionka drzwi do mieszkań, których jest kilka. W domach panuje czystość, a tak samo i w mieszkaniach.

Samuel Mordkowicz, gospodarz pierwszego domu karaimskiego, do którego wszedłem, jest mężczyzną czterdziestokilkoletnim, o czarnym zaroście włosów, z brodą (...). Mówi, chociaż nie zupełnie poprawnie, lecz znośnie dobrze po polsku, bez żydowienia i z czystą wymową, po rusku zaś jeszcze lepiej i czyściej, co się tem tłómaczy, że obcuje po największej części z ludem ruskim, zamieszkującym przedmieściu Halicza i wsie okoliczne. Strojem różni się też od Żyda. Ma na sobie ciemną kapotę zwykłego kroju, sięgającą kolan, buty z cholewami, sięgającemi prawie kolana, w które wpuszczone są nogawice spodni.

- My do nikogo nie czujemy nienawiści - mówił do mnie, wprowadzając mnie do swojego domu - ot, tam, drugie drzwi, mieszka u mnie na komornem jeden Żyd. Jeśli pan chce wejść do izby, to proszę, a jeśli nie, to pójdę po klucze od świątyni i zaraz je przyniosę.

Przyjąłem zaproszenie bardzo chętnie i weszliśmy do izby.

- U nas ubogo - rzekł ale chędogo. Niech pan spocznie trochę.

W izbie, dość przestronnej i jasnej, istotnie było bardzo czysto. Ściany bielone, podłoga czysto wymyta. Kanapa, stół, krzesła, łóżko i maszyna do szycia, pod oknem nieduża, oszklona szafka, wszystko naturalnie niewykwintne, lecz porządne, stanowiły jej umeblowanie. W szafce znajdowały się księgi, w skórę oprawne, z wyglądem starożytnym.

- Ma pan rodzinę? - zapytałem gospodarza domu. 
- Bogu dzięki, mam - odpowiedział - żonę, dwie córki i chłopca. Ester! - zawołał - pójdź tu, mamy gościa.

Gdy, mimo wołania, nikt się nie zjawił w pokoju, tłómaczył mi p. Mordkowicz.

- Żona moja, Estera, jest przy gospodarstwie. Nie jest ubrana tak, aby pana mogła powitać. Kobiety, jak wszędzie, lubią stroić się, a broń Boże, żeby ich gość dostojniejszy miał zobaczyć tak jak są w domu. Na to rady niema.

Po chwili, zamiast pani Estery Mordkowiczowej, ukazała się panna Judyta Mordkowiczówna, przystojne dziewczę lat szesnastu lub siedemnastu, schludnie w perkalikową suknię ubrana.

- To moja córka najstarsza Judyta - rzekł, przedstawiając mi ją. Choć jeszcze niema spełna szesnaście roków, bardzo sprytnie bierze się do gospodarstwa i jest prawą ręką matki.

Panienka o wyglądzie czerstwym wieśniaczki poruszała się dość śmiało.

- A pan z daleka? - zagadnęła mnie.

- Przyjeżdżam wprost z Wiednia do Halicza - odpowiedziałem.

- Aż z Wiednia - podjęła ze zdziwieniem - to musi bardzo daleko, dalej jak Lwów.

- Co Lwów - podjął jej ojciec - to bardzo, bardzo daleko. Tam siedzi nasz pan najjaśniejszy i łaskawy monarcha-cesarz. Ale, doprawdy - podjął, zwracając się ku mnie i wzrokiem obserwując mnie bystro - że też szanownemu panu chciało się jechać z tak wielkiego miasta do naszej mieściny i po co właściwie? - zapytał mnie badawczo - Czy może w interesach handlowych?

- Nie - odparłem. - Korzystałem z świąt, z wolnego czasu i przybyłem tu, by zobaczyć i poznać was, karaimów.

- Nas? - podjęli odgłosem razem ojciec i córka, spoglądając na siebie ze zdziwieniem i pewnem niedowierzaniem.

Potem rzekł gospodarz domu:

- A cóż to tak osobliwego u nas, żeby pan aż z Wiednia przyjeżdżał tu.

- Chcę poznać wasz lud, o którym słyszałem i czytałem nieco, na miejscu, mam bowiem zamiar napisać nieco o was.

- Pan nas chce opisać - zauważyła Judyta. - Wie ojciec, tamtego roku był tu także taki pan - p. Grzegorzewski, który siedział w Haliczu kilka tygodni.

- Wiem, wiem - odparł Mordkowicz, a po namyśle, zwracając się ku mnie, rzekł: - Niech pan tam nic złego o nas nie pisze. My nikomu nic złego nie robimy. Żydzi jednak czernią nas, gdzie tylko mogą.

Uspokoiłem gospodarza domu, a gdy rozproszyłem obawy i podejrzenia, drzemiące w skrytości jego umysłu, stał się o wiele mowniejszym i poufalszym. Tłómaczył się następnie:

- Człowiek w dzisiejszych czasach nic może wiedzieć, z kim ma do czynienia. My nikomu wody nie mącimy, pracujemy ciężko na kawałek chleba, pracujemy uczciwie, a przecież mamy wrogów. Żydzi nie mogą nam przebaczyć naszego zeznania. Wiedzą oni, że choć nas mało jest, to przecie przyjdzie czas, że cały świat będzie karaimski.

Ostatnie słowa wygłosił z namaszczeniem silnej wiary. 
Z dalszej rozmowy dowiedziałem się, że gmina karaimska w Haliczu ma swojego własnego rabina. Zowie się on Nowachowicz, pochodzi z Kukizowa, a uczył się w Eupatorji. Ma też własną szkolę wyznaniową. Nauczycielem, który się zowie w narzeczu iwretiwci jest haliczanin, Józef Leonowicz. W szkole uczą gramatyki hebrajskiej, biblji i pism Mojżesza, przepisów obrzędowych, „nauki kalendarza” i „wszystkiego, co religja wymaga i nakazuje”. Dzieci karaimskie uczęszczają równocześnie do miejskiej szkoły ludowej i wydziałowej.

- Mamy tu i takich - opowiadał mi Mordkowicz - którzy kończą i wyższe szkoły: c.k. adjunkt sądowy w Buczaczu p. Józef Samuelowicz, skończony prawnik, jest karaimem z Halicza. W Krakowie zdaje tego roku malarz, jeden z naszych, nazwiskiem Nowachowicz; w Brzeżanach chodzi do klasy 7 gimnazjalnej Murek Szulemowicz, no a pan ferwalter ${ }^{8}$ przy okrętach w Haliczu jest także rodowitym Karaimem.

Zapytałem Judytę, jakie pieśni śpiewają dziewczęta karaimskie?

- Domowe pieśni są u nas religijne - odpowiedziała.

- A świeckich niema?

- Śpiewamy i po świecku czasem, ale to są zwykłe polskie lub ruskie piosenki, jak je śpiewają dziewczęta chrześcijańskie.

- A baśni i bajek u was nie opowiadają sobie?

- Nie, - odparł Samuel Mordkowicz - my trzymamy się ściśle Pisma świętego.

- Więc są może jakie podania? - pytałem dalej.

- Podania są w naszych księgach.

- Cóż mówią ludzie wasi o waszem osiedleniu się w Polsce?

Na to począł Samuel Mordkowicz opowiadać:

- Będzie temu więcej niż lat 600, prawie 700, kiedy książę Witold jechał przez Krym. Wtedy właśnie dzieci uczyli się w medrasie - medras znaczy po naszemu szkoła - proroctw Jzajasza. Kniaziowi spodobał się ton naukowy, więc kazał stanąć i wszedł do medrasa, a potem sprowadził sobie karaimów do polskich i „litowskich” krajów i osiedlił we Lwowie, Kukizowie i Haliczu ośmdziesiąt rodzin karaimskich. Od kiedy jesteśmy w Haliczu, jest już 658 lat - dodał.

Potem poszliśmy do świątyni, zwanej po karaimskiu kensa. Jest to nieduży, murowany budynek, okrągły, dość nizki, zakończony u góry kopułą. Znajduje się na zewnątrz w dość zaniedbanym stanie i nie posiada żadnych zalet architektonicznych, ani ozdób. Wnętrze przedstawia się bardzo oryginalnie. Sklepiony sufit, niebieskawo pomalowany, a na nim porozrzucane gwiazdy złociste. Ma to zapewne przedstawiać horyzont nieboskłonu. Ściany przedstawiają cały szereg namalowanych tablic z napisami hebrajskiemi, poprzykrywanych jedwabnemi firankami (parochet) z rozmaitych materji, między tem i brokaty złotem tkane. Ołtarz, hechał, przed którym stoją dwa siedmioramienne świeczniki, a u góry wiszą dwa świeczniki bronzowe, składa się z dwu, ozdobnie oprawionych, zapisanych tablic.

- W te makaty -objaśniał mnie Samuel Mordkowicz - ubierały się dawniej nasze kobiety. Za starych czasów przodkowie nasi byli bogaci. Prowadzili wielki

${ }^{8}$ Administrator, zarządca (red.). 
handel. Gdy dawniej u nas kobieta ubrała się, to była w złocie od stóp do głowy, a nasza ulica karaimska w Haliczu zwała się Złotą ulicą.

- A jak stroili się dawniej mężczyźni u was?

- Chodzili w polskich strojach, a na głowie nosili piękne czapki baranie.

W kącie kensy znajduje się w szafce książnica. Prawie same stare księgi z XVI i XVII w., nowszych mało. Jest jedna stara biblja pół na pół hebrajsko-polska. Brak w niej karty tytułowej. Są księgi drukowane w narzeczu karaimskim głoskami hebrajskiemi, modlitewniki i śpiewniki. Poprosiłem mojego cicerone, żeby mi nieco odczytał z takiej książki.

- Są tu - rzekł - rozmaite rzeczy. Modlitwy, pieśni, przysłowia.

Następnie począł czytać:

- „Kim erte turad, anar tenri berlet.“

- Co to znaczy? - zapytałem.

- Kto rano wstaje, temu pan Bóg daje. - Potem czytał dalej: „Kim esłejde anar tenri bałusade" - dodając: Kto robi, temu Bóg dopomaga.

- Proszę odczytać mi jedną z pieśni - poprosiłem go następnie. Uśmiechnął się na to, mówiąc:

- Ja mogę odczytać i więcej niż jedną pieśń, cóż z tego, kiedy pan nic nie zrozumie.

- To mi pan wytłómaczy.

- Tak, mogę, ale ja do tego niebardzo sposobny.

Odczytał mi następującą zwrotkę:

„Azis dzanym mnim

Sarnama ojanhen,

Tenrenin hermetli

Machtavun kotarhen!

(Święta duszo moja, do modlitwy zbudź się, Boga miłosiernego wielkość opiewaj!)

Potem pokazywał mi narodowy kalendarz karaimski, oprawiony w złocone ramy i za szkłem złożony, o którym powyżej już wspomniałem. Nauczyciel wspólnie z rabinem pisze go corocznie na kartonie.

- Szkoda, że pan nie może - mówił dalej - czytać naszych ksiąg. Jest to czyste „zeznanie” Abrahama i Mojżesza. U nas talmud nic. Przyłączył się do nas sąsiad Mordkowicza, Samuel Eszłowicz, mężczyzna silnej budowy ciała, o rysach twarzy daleko mniej semickich, ubrany podobnie, jak klucznik świątyni. Mówił lepiej od tego polsku, wyrażał się bardzo rozsądnie, a czasami nawet poprawnie.

- Mój sąsiad - rzekł Samuel Mordkowicz - młodszy, więcej uczył się w szkole miejskiej, może panu lepiej wyłożyć i objaśnić. Ja jestem więcej uczony co do naszego „zeznania”.

Samuel Eszłowicz zaprosił mnie następnie do siebie.

Dom jego przedstawia mniej więcej ten sam typ budowlany, co i siedziba Mordkowicza. Więcej tylko wewnątrz ładu i porządku. Pokój, do którego mnie zaprowadził, czysto utrzymany, chociaż urządzenie skromne, podobnie jak u sąsiada. Zasiedliśmy przy dużym stole, przykrytym obrusem kolorowym. Gospodarz domu objaśniał mnie o karaimskich praktykach religijnych i zwyczajach karaimskich. 
- Szkoda wielka, - mówił - że niema w domu naszego rabina. Światły to i oczytany mąż, on by mógł panu więcej opowiedzieć. Nasze wszystkie zwyczaje religijne stosują się jak najściślej do przepisów mojżeszowych. Żyjemy podług tych przepisów najsumienniej. Mojżesz zabrania na przykład palenia ognia i światła w piątek w nocy, dlatego u nas, karaimów, nawet w największe mrozy w piątek w nocy mieszkań się nie opala. Tego u żydów niema. Oni każą sobie palić w piecu chrześcijanom, a tłómaczą sobie przepis Mojżesza tak, że tylko im samym niewolno palić, innym jednak mogą kazać zapalić. To jest wykręt. Inny może sobie palić, ile mu się podoba, ale nie u nas, bo Mojżesz zakazuje nam palenia światła i ognia w naszych mieszkaniach. Żydzi albo nie rozumieją dobrze ksiąg świętych, albo nie chcą ich rozumieć. Naprzykład przepis Mojżesza ustanawia, że jagnięcia nie wolno gotować w mleku. Żydzi żadnego mięsa w mleku nie gotują. My, trzymając się przepisu ściśle, gotujemy każdej soboty kurę w mleku. Co jagnię, to nie kura albo wół. U nas niema tej nienawiści do goimów (innowierców). Żyjemy w najlepszej zgodzie z chłopami i wszystkiemi chrześcijanami. U nas każdy bliźni i kochamy go tak, jak przykazuje Pan Bóg. Pracujemy też, jak każdy inny, czy to przy rolnictwie, rzemiośle lub chowie bydła. Gdzieniegdzie zajmujemy się także i handlem, ale uczciwie.

Spostrzegłem na stole zapisaną tekę papieru. Był to rodzaj gramatyki narzecza karaimskiego, w języku polskim napisanej przez syna gospodarza domu, Leona Eszłowicza, który ukończył szóstą klasę wydziałową. Z wielką ciekawością wziąłem tekę do ręki i zacząłem odczytywać treść. Gramatyka popularnie napisana według wszelkiej formy.

Przy rzeczownikach jest słowniczek: ojciec - ata, matka - ana, syn - uwat, córka - kyz, brat - karyndus, siostra - tuwduk, koń - at, krowa - inek, wół - egiz, owca - koj, świnia - tonhuz, pies - it, kot - maci, kura - tawuk, gęś - kaz, głowa - bas, ręka - kol, noga - ajak, oko - kez, ucho - kułak, nos - barun, usta - erin, ząb - kiś, palce - barmak, woda - suw, wódka - raki, ziemia - jer, drzewo - ahac albo otun, miasto - sahar, wieś - sałah, ptak - cipcik, chłopiec - cocka, człowiek - adam, miesiąc - aj, gospodarz domu - iwbey, chleb - etmek itd.

- To napisał sobie - rzekł Samuel Eszłowicz - mój syn Leon. On panu to sam wytłómaczy najlepiej.

Po chwili stanął przede mną piękny, szesnastoletni chłopak, brunet z czarnemi jak węgiel, błyskotliwemi oczyma i nadzwyczaj inteligientnym wyrazem twarzy. Po polsku mówił bardzo dobrze i poprawnie.

- Napisałem sobie to w wolnym czasie, - mówił mi. - W tym roku już nie uczęszczam do szkoły, skończywszy w zeszłym roku szóstą klasę. Wolnego czasu mam dość, bez zajęcia nudzi mi się, więc czytam i piszę sobie.

Zaprosiłem go, by usiadł przy mnie, i zaczęliśmy razem przeglądać rękopis gramatyki.

- Gramatyka narzecza naszego prosta. Mamy - objaśniał mnie - jedno tylko przypadkowanie rzeczownika, a przypadków sześć. Liczba mnoga tworzy się przez dodanie końcówki -łar, np. matka - ana, matki - anałar; ptak - cipcik, ptaki - cipcikłar itd. (...) 
Przerzuciliśmy kilka kartek dalej, zatrzymując się przy liczebnikach:

- Liczenie u nas także bardzo proste - mówił młody Eszłowicz: Jeden - bir, dwa - eki, trzy - ic, cztery - dert, pięć - bes, sześć - atty, siedm - jedi, ośm - segis, dziewięć - tohuz, dziesięć - on, dwadzieścia - egermi, trzydzieści - otuz, czterdzieści - kyrk, pięćdziesiąt - enli, sześćdziesiąt - ałtymys, siedmdziesiąt - jetmis, ośmdziesiąt - seksen, dziewięćdziesiąt - toksan, sto - iz. (...)

Wykład gramatyczny przerwała wejściem swym do pokoju pani Rachela Eszłowiczowa, żona Samuela, a matka Leona, kobieta silnie zbudowana, czerstwa, czysto ubrana, wyglądająca zupełnie na małomieszczankę wschodnią galicyjską. Roztropnemi oczyma zmierzyła mnie badawczo, mówiąc następnie:

- Że też panu chciało się z tak daleka przyjechać do naszej lichej mieściny! My ludzie biedni, ale uczciwi. Pracujemy ciężko, a wiernie trzymamy się naszej wiary i zeznania.

- Chciałem - odrzekłem - bliżej poznać wasz ludek.

- Prawda, - podjęła - my, karaimy, jesteśmy małym ludem. Dawniej było nas o wiele więcej: w Haliczu, Kukizowie, we Lwowie; teraz jest nas tylko garstka, ale, da Bóg, będzie nas więcej - wszystko w Jego ręku. Jak się panu u nas podoba?

- Bardzo.

- Miałabym wielką prośbę do pana. Jeżeli pan będzie o nas co pisał lub mówił, niech pan o nas nic złego nie pisze i nie mówi. My spokojni ludzie, nikomu nie mącimy wody i nie zawadzamy.

- Nie mam żadnego powodu mieć o was złe mniemanie. Owszem, to, co widzę i słyszę, daje mi o was jak najlepsze wyobrażenie. Niech pani co do tego będzie zupełnie spokojną.

- Przepraszam, żem może uchybiła, ale człowiek nigdy nie może wiedzieć, $\mathrm{z}$ kim ma do czynienia.

- Kobiety - rzekł Samuel Eszłowicz - są zawsze podejrzliwe. Już to taka natura babska.

- Przecież ja nic złego nie powiedziałam - usprawiedliwiając się, podjęła Rachela.

- Bynajmniej - odparłem.

- Pan - tłómaczył Samuel Eszwowicz - ciekawy jest poznać bliżej Karaimów, o których zapewne czytał w książkach. Jeżeli to były książki żydowskie, to pewno przedstawili nas tak czarnych, jak kominiarzów. Dlatego dobrze, że pan sam zobaczy i przekona się na własne oczy.

Potem dodał, z uśmiechem zwracając się do żony:

- Ty myślisz zapewne, że tylko kobiety są ciekawe? W świecie naukowym są też ciekawi mężczyźni. A stary kanonik ruski, który tu zjeżdża ze Lwowa i kopie na Załukwi i Kryłosie tygodniami i zbiera wszystkie stare czerepy, gwoździe i co tylko znajdzie w ziemi. To są ludzie bardzo ciekawi nauki, którzy z bagatelki, chociażby czerepu lub gwoździa, odgadują, co dawniej było i jak było.

- My, kobiety, nie rozumiemy się na tem - odparła Karaimka, a następnie, zwracając się do mnie, zapytała: 
- Czego właściwie chce się pan dowiedzieć?

- Wszystkiego: Jak żyjecie, jak bawicie się, jakie u was zwyczaje i obyczaje, jakie są wasze opowieści, jakie pieśni śpiewacie...

- U nas opowieści - przerwała mi - tylko z Pisma świętego, a pieśni także tylko duchowne.

- 0, o! - wtrącił Samuel Eszłowicz - jest w tem tylko pół prawdy. Dziewczęta śpiewają także świeckie pieśni. A moja żona, Rachela, śpiewała z nich najlepiej i dziś jeszcze śpiewać umie. Zaśpiewaj-że co panu.

- Co tobie znowu chodzi po głowie? - wzbraniając się, odrzekła.

Poprosiłem i ja ją pięknie, żeby co zaśpiewała; w końcu, po dłuższem wahaniu się, zaśpiewała pięknym i silnym głosem:

„Zapriahajte koni w sanki,

Pojidemo do kochanki.

Pryjichaty pred worota,

Wyjszła myła, szczyro-złota."

- Jak dalej, zapomniałam - odezwała się, urwawszy na pierwszej zwrotce. Ale zaśpiewam panu co innego:

„A gdzież ten, co mnie chciał,

Co mi zagrać obiecał?

On tam stoi za lasem,

Trzyma świder za pasem.

Biegł pies przez owies,

Suczka przez tatarkę,

Niósł pies bębenek,

A suczka sopiałkę."

Potem zaśpiewała mi jeszcze pieśń o słynnym staroście kaniowskim i młynarzu, zaczynającą się słowy:

„U naszego młynarza

Jest tam ładna dziewczyna.

A pan o niej nie wiedział,

Służeńka mu powiedział,

Oj, posłał pan dragona:

„Idź, młynarzu, do pana”.

Idzie młynarz i duma:

„Co ten pan do mnie ma?

Oddałem mu podatki

I od młyna drapaczki."

Kobiecina rozśpiewała się na dobre, aż rumieńce okrasiły jej lica.

- Teraz będzie pan miał dosyć śpiewu - rzekł Samuel Mordkowicz, gdy skończyła rzecz o staroście kaniowskim.

Wróciliśmy z Leonem Mordkowiczem do gramatyki karaimskiej.

- Czasowanie jest u nas - podjął - także proste. Mamy wszystkie czasy, tryby i imiesłowy. Oto czasownik kazma - kopać. Czas teraźniejszy - zaman haligi-: 
kazamen - kopię, kazasen - kopiesz, kazady - on, ona, ono kopie; kazabiz - kopiemy, kazasiz - kopiecie, kazadylar - oni kopią. (...)

Po przejrzeniu gramatyki, rzekłem do Leona:

- Powinieneś pan opracować całą gramatykę narzecza karaimskiego, z dodaniem słownika. Będzie to praca pożądana dla polskiego piśmiennictwa naukowego. Sądzę, że nakładcę łatwo będzie można znaleźć: krakowska Akademja Umiejętności powinna by wydać to swoim kosztem, a pan otrzyma za pracę swoją drogą wynagrodzenie odpowiednie.

- Jakże mi trafić - odparł - do Akademji?

Zachęcałem go bardzo do podjęcia tej pracy, zwłaszcza, iż układ pisanej gramatyki był wcale dobry, a chłopak wydał mi się bardzo zdolnym. Sam już jego pomysł - pisania po polsku gramatyki narzecza - zasługiwał na uwagę. Obiecał mi, że weźmie się do napisania gramatyki i słownika, a ja obiecałem mu zająć się wyszukaniem nakładcy.

Bawiłem przeszło dwie godziny w domu Eszłowiczów. Przy pożegnaniu gospodarz domu, ściskając mi dłoń, mówił:

- Niech pan o nas zachowa dobrą pamięć. My biedni, lecz uczciwi ludzie. Mało nas jest, to prawda, ale w Piśmie świętem stoi, że kiedyś - da Bóg - cały świat będzie karaimskim.

Mówił to samo, co mi był rzekł przedtem Samuel Mordkowicz, a mówił z takiem samem namaszczeniem silnej wiary, jak tamten.

Tymczasem liczba Karaimów wciąż się zmniejsza. Zjawisko to głównie przypisać należy okoliczności, iż od wieków żenią się tylko pomiędzy sobą, w szczupłem gronie gminy wyznaniowej, która w Haliczu nie dosięga nawet dwustu głów.

\section{Od redakcji}

Ach, ci dziennikarze! - chciałoby się powiedzieć. Coś usłyszą, coś przekręcą, coś pomylą. Tak bywa teraz, tak bywało też przed ponad stu laty. Pan Grzegorz Smólski, który spisał swe wrażenia ze spotkania z halickimi Karaimami, również nie ustrzegł się paru nieścisłości, które utrudniają identyfikację wymienionych w tekście osób. Samuel Mordkowicz jest jak najbardziej postacią rzeczywistą. Urodzony w 1848 r. w rodzinie, która wydała wielu hazzanów i mężów uczonych w Piśmie, w latach 1922-1924 pełnił obowiązki hazzana. Udzielał także lekcji religii karaimskim dzieciom. Dożył sędziwego jak na owe czasy i warunki życia wieku 82 lat i zmarł w Haliczu w 1930 r. Był dwukrotnie żonaty, ale żadna z jego małżonek nie nosiła imienia Ester! Nie miał również dwóch córek i syna, jak pisze pan Smólski, lecz jedną córkę i dwóch synów (oprócz dorosłego i od dawna żonatego już wówczas syna z pierwszego małżeństwa), a trzeci miał się urodzić za kilka miesięcy. Córka nie miała na imię Judyta (takie imię wśród 
halickich Karaimów, którzy nadawali dzieciom imiona po zmarłych krewnych, w ogóle nie występowało), lecz Zofia (Szełomit) i w czasie wizyty pana Smólskiego miała lat 12 , nie 16.

Żonę Esterę i 15-letnią córkę miał za to Jakub-Józef Leonowicz, rówieśnik Samuela Mortkowicza, późniejszy hazzan w Łucku (i prawdopodobnie wspomniany przez Smólskiego iwretiwci, czyli nauczyciel). Szkopuł w tym, że żona zmarła w 1893 r., a córka miała na imię... Sara. Warto w tym miejscu wspomnieć, że jej starsza siostra, Ryfcia stała się językową informatorką Jana Grzegorzewskiego, autora wspomnianej w artykule pierwszej pracy naukowej o języku halickich Karaimów. Kto więc otworzył przed panem Smólskim drzwi kienesy, a kto zaprosił go do swego domu?

Drugi gospodarz to także postać autentyczna. Samuel Eszwowicz (Eszłowicz to fonetyczny zapis ukraińskiej wymowy tego nazwiska) żył w latach 18611942. Jego syn, Leon (1887-1947) do „Akademji” nie trafił - wybrał edukację religijną. Ukończył Wyższą Karaimską Szkołę Duchowną w Eupatorii i w okresie międzywojennym był nauczycielem w karaimskiej szkółce w Haliczu. Kłopot znowu sprawia kobieta - żona Samuela miała na imię... Estera, nie Rachela! Z domu Nowachowicz, była siostrą Szałoma, ówczesnego hazzana (w czasie wizyty Smólskiego nieobecnego w Haliczu).

Z innych Karaimów wspomnianych w artykule Józef Samuelowicz (18681929) „c.k. adjunkt sądowy w Buczaczu, skończony prawnik”, był później sędzią w Złoczowie, a uczęszczający do klasy siódmej gimnazjalnej Marek Sulimowicz (1882-1906) wkrótce miał rozpocząć studia medyczne we Lwowie, które następnie kontynuował w Krakowie. Niestety, zmarł przedwcześnie krótko przed ich ukończeniem . Pamięć gminna niestety nie przechowała informacji, kim był wspomniany malarz w Krakowie i jak potoczyły się jego losy ani jak nazywał się „pan ferwalter przy okrętach w Haliczu”.

Niewolne od błędów są próbki języka karaimskiego przytoczone przez pana Smólskiego. Nie ma jednak co go za nie winić, era dyktafonów przecież jeszcze wtedy nie nastała. Teksty te pozostawiliśmy niezmienione, podobnie jak w większej części zachowaliśmy ortografię i interpunkcję oryginału. Warto bowiem docenić ten artykuł jako jedno z nielicznych źródeł informacji, choćby i nie do końca ścisłych, o życiu tej ongiś kipiącej życiem, a dziś już właściwie wymarłej karaimskiej gminy. 